\title{
Locally Extensive
}

National Cancer Institute

\section{Source}

National Cancer Institute. Locally Extensive. NCI Thesaurus. Code C120858.

Being widespread throughout a specific area. 